\title{
Do the structures of macaw palm fruit protect seeds in a fire-prone environment?
}

\author{
Elisa Monteze Bicalho', Bruno Luan Rosa², Anna Elisa de Souza², Camilla Oliveira Rios ${ }^{2}$ \\ and Eduardo Gusmão Pereira ${ }^{2 *}$
}

Received: March 9, 2016

Accepted: September 20, 2016

\begin{abstract}
Fire is an abiotic disturbance that regulates vegetation structure and biodiversity. Some plant species have adapted to fire prone environments by evolving protective structures. Acrocomia aculeata (macaw palm) is widely distributed throughout tropical America, and is found in environments continuously influenced by anthropogenic fire. We aimed to determine whether the fruit characteristics of $A$. aculeata enable seeds to resist the effects of fire and also the consequent effects of fire on fruit biometric traits and embryo viability. After a fire event in a region of pastureforest transition, we marked 30 individuals of $A$. aculeata. The trees were separated by UPGMA analysis into 5 groups according to fire exposure, ranging from trees with no exposure to trees with fruit completely exposed to fire. Fruit exposure to high temperatures led to lower values in fruit fresh weight, length, density, and processable mass.Fire had no significant effect on seed biometric variables, because of the structures of the fruit, including its lignified endocarp and its insulating and mucilaginous mesocarp. These structures helped to maintain the embryos viability by preventing oxidative damage. In conclusion, the fruit structure of the macaw palm may facilitate seed persistence, even when subject to increasingly frequent fire events.
\end{abstract}

Keywords: Acrocomia aculeata, biometry, burning, climate change, seed viability

\section{Introduction}

Fire is an abiotic factor that has become increasingly frequent since the second half of the last century. This change is due to an influx in human activities linked to wood exploitation, mining, and the expansion of agricultural boundaries, in parallel with climate change, leading to more intense seasonal drought events coupled with higher air temperatures (Slik et al. 2010). Fire affects the structure and composition of vegetation in all terrestrial ecosystems. Fire primarily impacts floristic composition, in addition to the structure and dynamics of the plant community, by eliminating sensitive species through the complete incineration of seedlings, young plants, and adult plants. Fire also hampers certain biological processes, including flowering, fruit production and development, and seed viability, dispersal, and germination (Trabaud 1987; Gignoux et al. 1997). Plants may persist after fire by resprouting from below-ground structures (Clarke et al. 2013) or by having existing structures, such as thick bark, that provides protection to live meristems during the passage of fire (Gignoux et al. 1997; Pausas 2015).

Persistent traits in the seeds of some plant species also facilitates population resilience after fire events, and

\footnotetext{
${ }^{1}$ Instituto de Ciências Biológicas, Departamento de Botânica, Universidade Federal de Minas Gerais, 31270-901, Belo Horizonte, MG, Brazil

${ }^{2}$ Instituto de Ciências Biológicas e da Saúde, Universidade Federal de Viçosa, Campus UFV-Florestal, 35690-000, Florestal, MG, Brazil

* Correponding author: egpereira@ufv.br
} 
may determine the physiognomy of vegetation together with the plant resprouting capacity (Russell-Smith et al. 2012). Some plant species have structures in their seeds or fruit that provide a protective role against the high temperatures reached during fires (Kozlowski \& Pallardy 2002). Populations of propagule-persister species tend to have thick seed coats and long-lived seed banks, with the recruitment of new individuals often being enhanced by fire (Pausas et al. 2004; Ooi et al. 2014). In fact, fire may act as a natural agent breaking seed dormancy and facilitating germination in some legumes (Danthu et al. 2003; Williams et al. 2003) and other plant species (Reyes \& Trabaud 2009; Moreira et al. 2010).

The macaw palm, Acrocomia aculeata is an oleaginous palm species that has a thick lignified endocarp (Reis et al. 2012). This endocarp might act as a protective structure when the palm is exposed to high temperatures promoted by fire. This species also has a low germination rate that is due to physiological traits, rather than physical dormancy (Ribeiro et al. 2011; Bicalho et al. 2015). A. aculeata is widely distributed throughout tropical America (Motta et al. 2002; Pires et al. 2013). It is a pioneer species that colonizes pastures and open areas in the Cerrado domain, which is prone to frequent fire events. Understanding the physiological responses of macaw palm seeds to fire could help improve the design of conservation strategies facilitating the succession, establishment, and regeneration of plants on degraded lands.

Here, we investigate how the fruit structures of the macaw palm contribute to the protection of seeds exposed to fire in its natural environment, by evaluating the viability and lipid peroxidation of macaw palm embryos in relation to biometric traits.

\section{Materials and methods}

\section{Study site}

The area consists of a pasture region near a forestry area, located c.a. $6 \mathrm{~km}$ north of Florestal City (19 $53^{\circ} 22^{\prime}$ S, 44 $25^{\prime} 57^{\prime} \mathrm{W}$ ), Minas Gerais, Brazil. For the purposes of this study, meteorological data were obtained from station number 83581 of the Brazilian National Institute of Meteorology (INMET; http://www.inmet.gov.br/portal/), which is located at the Universidade Federal de Viçosa, Campus UFV-Florestal. On October 1, 2011, the area was subject to a fire that reached the canopy of some trees. Within the burned area, 4 ha were used for sampling trees, which were randomly selected based on the fire intensity according to the height of fire scars (Hoffmann \& Solbrig 2003) on their stipes and bunches. The fire lasted two days. Rain was scarce in 2011, particularly between May and October (Fig. 1). The low precipitation regime and high temperature, which characterized the extended dry season of 2011, contributed to the fire continuing to spread for two days, until it stopped after rain. November and December of 2011 and January of 2012 were the rainiest months after the fire. The minimum and maximum temperatures in the dry season were about $13^{\circ} \mathrm{C}$ and $24^{\circ} \mathrm{C}$, respectively. The Florestal City region is positioned at an altitude of approximately $753 \mathrm{~m}$ above sea level in a transitional area between the Cerrado and Atlantic Forest, with a mosaic of natural vegetation, including savanna, secondary riparian forests, and semi-deciduous forest formations. The climate of the region is Aw based on the Köppen classification, with rainy summers and dry winters. It receives a mean of 1300 $\mathrm{mm}$ precipitation annually.

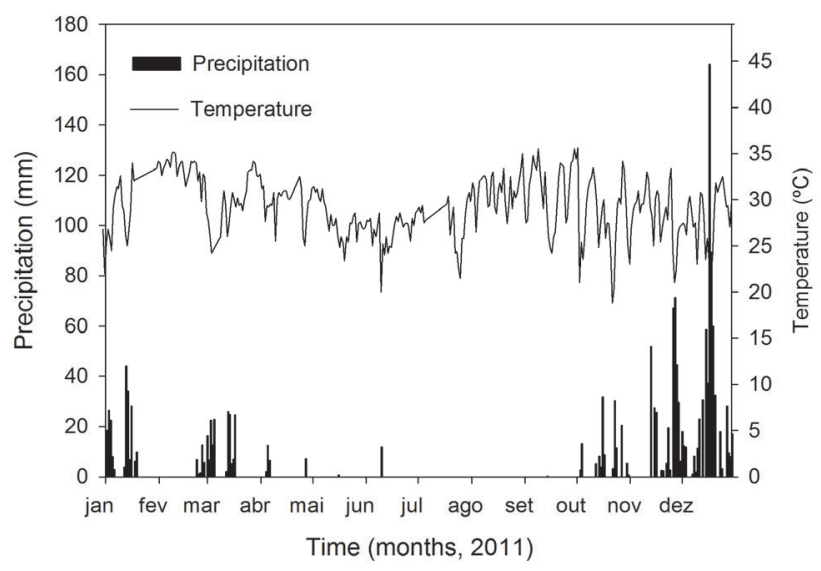

Figure 1. Climatological data during fruit development and the experimental period at Florestal City, Minas Gerais State, Brazil.

\section{Study species and experimental procedures}

Acrocomia aculeata (Jacq.) Lodd. ex Martius (macaw palm) is a perennial palm species that is wide-spread in tropical America. Macaw palm is classified as a pioneer species that grows in soils with high fertility, and where the original vegetation was composed of forests. This species avoids extreme conditions of water deprivation and nutrient scarcity (Motta et al. 2002).

Two days after the fire event, we randomly selected 30 individuals of macaw palms, and collected fruit that were at the final stage of reproductive development (Mazzottinidos-Santos et al. 2015). We marked 25 individuals that had been exposed to fire of different intensities, and 5 individuals that had not been affected by the fire in an adjacent area (controls). The trees were georeferenced with a GPS (Global Positioning System). Tree height, height of fire, height of bunches insertion, and the number of bunches were determined for each plant. In total, 150 fruit were collected from each macaw palm tree 2 days after the fire event, and were separated based on biometric and 
physiological measurements. Fruit from macaw palms where fire had reached the height of bunches (or higher) were collected from the soil, due to abscission. Fruit from trees where the fire had only reached the base, or where the fruit had not been damaged by the fire, were randomly collected from the bunches.

\section{Fruit sampling and biometric measurements}

For each macaw palm individual, 30 mature fruit were sampled; thus, 900 fruit were used for the biometric analysis. The fruit were transferred to the laboratory where the fresh weight of the whole fruit was measured, followed by that of the seeds, endocarp, and epicarp using an analytical balance (precision: $\pm 0.01 \mathrm{~g}$ ). The length of the seeds and the thickness of the endocarp were measured using a manual caliper. The volume of the seeds and fruit was estimated gravimetrically, through the volume of water that was displaced in a graduated cylinder when the fruit or seeds were submerged. The density of the fruit and seeds was obtained from the ratio between fresh mass and volume. The processable mass (mesocarp plus endosperm mass) was obtained by the difference between the fresh weight of the fruit and the non-processable components (endocarp plus epicarp mass). Seeds damaged by the presence of larvae were excluded from the biometric analysis.

\section{Physiological measurements}

The viability and vigor of macaw palm embryos were evaluated using the tetrazolium test (Ribeiro et al. 2010). Ten embryos from each tree were extracted from the fruits, and were incubated in $0.5 \%$ 2,3,5-triphenyl tetrazolium chloride ( $\mathrm{pH} 7.1$ ) for $4 \mathrm{~h}$ in the dark at $35^{\circ} \mathrm{C}$. Then, the embryos were washed in deionized water, and the red color pattern that formed was registered for each embryo using a stereomicroscope. Viability and vigor were determined from the intensity of color in specific regions of the embryo, following the description of Ribeiro et al. (2010).

To measure the extent of oxidative damage, the embryos were extracted from the seeds and the amount of malondialdehyde (MDA) was estimated, which is a product of lipid peroxidation. We followed the method of Du and Bramlage (1992), which takes into account interference caused by carbohydrates. Twenty-five embryos (approx. 100 $\mathrm{mg}$ ) from each tree were homogenated in $2 \mathrm{ml}$ of $0.1 \%(\mathrm{w} / \mathrm{v})$ trichloroacetic acid (TCA). The homogenate was centrifuged at $10,000 \times g$ for $15 \mathrm{~min}$, and $1.5 \mathrm{ml}$ of $0.65 \%(\mathrm{w} / \mathrm{v})$ TBA solution was added to $500 \mu \mathrm{l}$ of the supernatant. The test tubes were incubated in a water bath set to $95^{\circ} \mathrm{C}$ for 25 $\mathrm{min}$. The reaction was stopped by placing the test tubes in an ice bath. The samples were centrifuged at 3,000 $\times g$ for $10 \mathrm{~min}$, and the absorption of the supernatant was read at $532 \mathrm{~nm}$. The value for non-specific absorption at 440 and $600 \mathrm{~nm}$ was subtracted. The amount of MDA was calculated from the extinction coefficient $155 \mathrm{mM}^{-1} \mathrm{~cm}^{-1}$.

\section{Data processing and statistical analysis}

The data on bunch insertion height and the height of fire scars were used for the grouping analysis (UPGMA) measured with Euclidian distance. After grouping the trees, the similarity among the groups was assessed. The data on biometric analysis were distributed in frequency histograms, and the coefficient of variation was calculated, with the maximum and minimum values of each measured characteristic being presented. All data were checked for homogeneity of variance and normality, and were then analyzed using one-way ANOVA with entirely randomized design, in which "group" was the only independent factor. Data on the percentage of viable and vigorous embryos were transformed in $\arcsin \sqrt{ } \mathrm{x} / 100$ before statistical analysis. Differences between means were tested using Tukey's post hoc comparison. The level of significance was set to $P<0.05$. All statistical analyses were performed using Statistica 7 (StatSoft, Inc., USA).

\section{Results}

The 30 macaw palm trees that were sampled were separated into five groups by grouping analysis (UPGMA) measured with Euclidian distance, based on bunch height and the height reached by the fire (Fig. 2). Group 1 ( $\mathrm{n}=$ five individuals) contained trees that were not affected by the fire (control group). Group 2 ( $\mathrm{n}=$ seven individuals) contained trees that were only affected by the fire at the base of the stipe. Group 3 ( $n=$ nine individuals) contained trees that had burned close to the base of the bunch. Group 5 ( $\mathrm{n}$ = five individuals) contained trees with lower bunch insertion than group 4 ( $\mathrm{n}=$ four individuals); however, the bunches of these trees had been totally consumed by fire, with burned fruit (Tab. 1).

Bunches occurred at a height of $2.7 \mathrm{~m}$ (group 5) to 5.1 $\mathrm{m}$ (group 2), depending on plant height (minimum $4.9 \mathrm{~m}$ in group 5 and maximum $8.4 \mathrm{~m}$ in group 2). Each individual had 4 to 5 bunches, with low variation among the groups. On plants from groups 4 and 5 , the height of fire scars was higher than the height of bunches, whereas the fire did not reach the bunches in the other groups (Tab. 1).

Fruits directly exposed to high temperatures (groups 4 or 5) had increased abscission and lower values for fruit fresh weight, fruit length, fruit density, and processable mass. Groups 1, 2, and 3 had similar fruit biometry variables (Tab. 2). The frequency distribution of fruit fresh weight was more concentrated from 40 to $55 \mathrm{~g}$ in groups 1,2 , and 3. In contrast, the fruit fresh weight was more scattered in the groups with burned fruit (4 and 5), ranging from 19 to $50 \mathrm{~g}$. The same pattern was observed for the frequency distribution of fruit length (Fig. 3); however, only group 4 


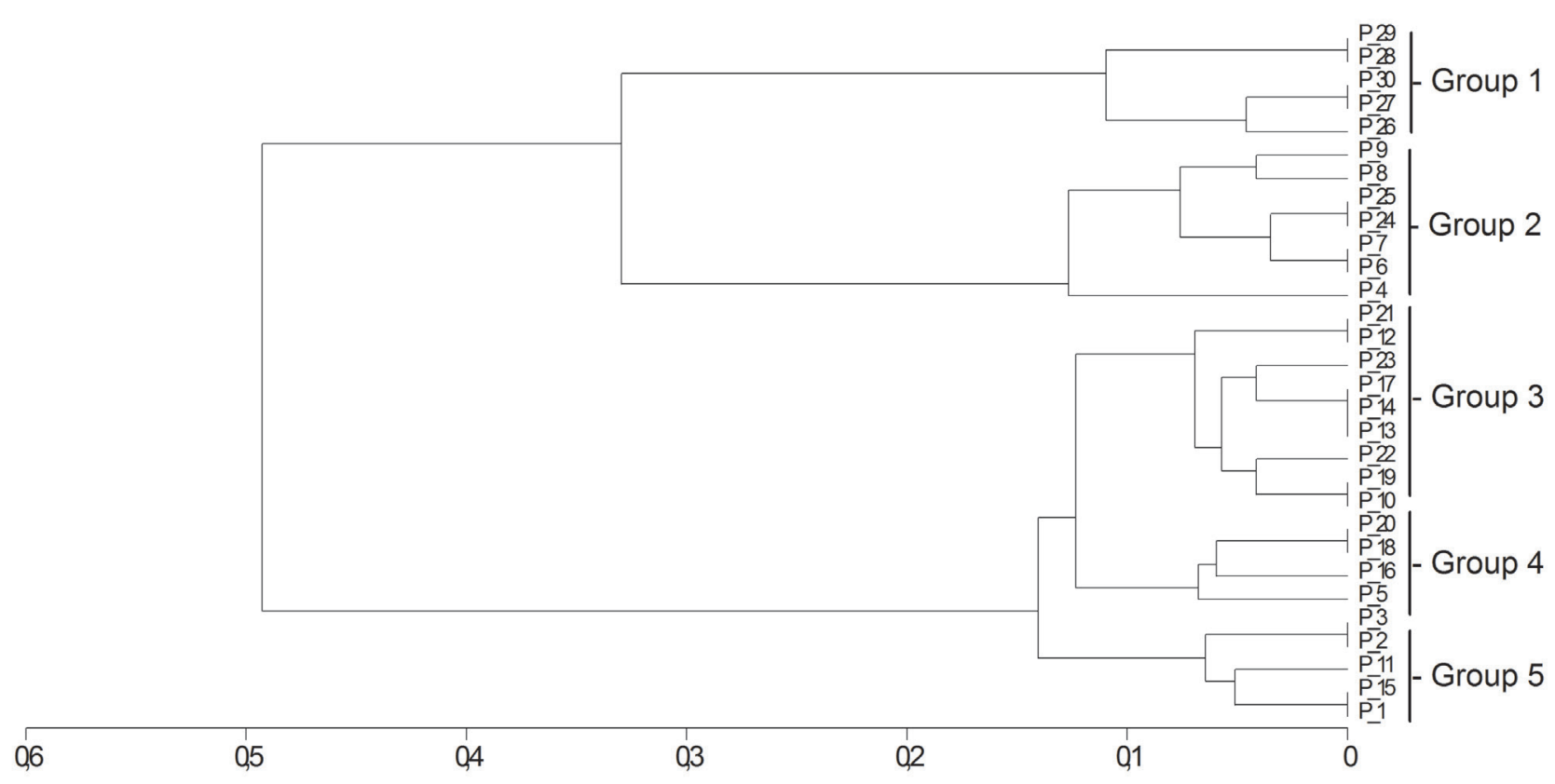

\section{Euclidean distance}

Figure 2. Grouping analysis of sampled Acrocomia aculeata individuals based on the height of bunches and visual estimates of the height reached by the fire. The 30 trees were separated into 5 groups based on similarities. Group 1: plants not affected by fire; Group 2: plants affected by fire at the stipe base; Group 3: plants affected by fire close to bunch height; Groups 4 and 5: plants affected by fire at bunch height, with burned fruit.

Table 1. Plant height (m), height of bunches (m), height of fire scars (m), and number of bunches per plant for Acrocomia aculeata individuals exposed to different intensities of fire in the field based on the tree groupings. Group 1: plants not affected by fire; Group 2: plants affected by fire at the stipe base; Group 3: plants affected by fire near to the bunches; Groups 4 and 5: plants affected by fire at bunch height, with burned fruit.

\begin{tabular}{|c|c|c|c|c|}
\hline & Plant height $(\mathrm{m})$ & Height of bunches $(\mathrm{m})$ & Height of fire scars $(\mathrm{m})$ & Number of bunches \\
\hline Group 1 & $7.1 \pm 0.5 \mathrm{ab}$ & $4.2 \pm 0.3 \mathrm{ab}$ & $0.0 \pm 0 \mathrm{~d}$ & $4.0 \pm 0.5 \mathrm{a}$ \\
\hline Group 2 & $8.4 \pm 0.6 \mathrm{a}$ & $5.1 \pm 0.2 \mathrm{a}$ & $1.1 \pm 0.1 \mathrm{c}$ & $5.1 \pm 0.3 \mathrm{a}$ \\
\hline Group 3 & $6.4 \pm 0.3 \mathrm{~b}$ & $4.0 \pm 0.1 \mathrm{~b}$ & $3.2 \pm 0.1 \mathrm{~b}$ & $5.6 \pm 0.3 \mathrm{a}$ \\
\hline Group 4 & $6.1 \pm 0.6 \mathrm{ab}$ & $3.8 \pm 0.1 \mathrm{~b}$ & $4.5 \pm 0.2 \mathrm{a}$ & $5.5 \pm 0.6 \mathrm{a}$ \\
\hline Group 5 & $4.9 \pm 0.3 \mathrm{~b}$ & $2.7 \pm 0.1 \mathrm{c}$ & $3.4 \pm 0.1 \mathrm{~b}$ & $4.0 \pm 0.3 \mathrm{a}$ \\
\hline
\end{tabular}

Means of groups followed by the same letters do not differ statistically of Tukey post-hoc comparisons $(\mathrm{P}<0.05)$.

Table 2. Maximum (max), minimum (min), variation coefficient (CV\%), mean and standard error of weight (g), equatorial diameter $(\mathrm{mm})$, density $\left(\mathrm{g} \mathrm{cm}^{-3}\right)$ and processable mass $(\mathrm{g})$ of Acrocomia aculeata fruits exposed to different intensities of fire in the field. Group 1: plants not affected by fire; Group 2: plants affected by fire at the stipe base; Group 3: plants affected by fire near to the bunches; Groups 4 and 5: plants affected by fire at bunch height, with burned fruits.

\begin{tabular}{|c|c|c|c|c|c|c|c|c|c|c|c|c|c|c|c|c|}
\hline & \multicolumn{4}{|c|}{ Fruit fresh weight [g] } & \multicolumn{4}{|c|}{ Fruit lenght (mm] } & \multicolumn{4}{|c|}{ Fruit density $\left[\mathrm{g} \mathrm{cm}^{-3}\right]$} & \multicolumn{4}{|c|}{ Processable mass [g] } \\
\hline & $\max$ & $\min$ & $\mathbf{C V}_{\%}$ & mean & $\max$ & $\min$ & $\mathrm{CV}_{\%}$ & mean & $\max$ & $\min$ & $\mathrm{CV}_{\%}$ & mean & $\max$ & $\min$ & $\mathbf{C V}_{\%}$ & mean \\
\hline Group 1 & 61.3 & 21.0 & 17.0 & $46.3 \pm 0.6 a$ & 49 & 35 & 6.1 & $42.9 \pm 0.2 \mathrm{a}$ & 1.71 & 0.78 & 12.9 & $1.12 \pm 0.01 \mathrm{a}$ & 38.7 & 5.6 & 26.6 & $27.1 \pm 0.7 a$ \\
\hline Group 2 & 59.4 & 23.4 & 13.0 & $44.9 \pm 0.4 \mathrm{a}$ & 48 & 33 & 4.8 & $42.8 \pm 0.1 \mathrm{a}$ & 1.92 & 0.61 & 13.8 & $1.15 \pm 0.01 \mathrm{a}$ & 43.4 & 3.5 & 22.1 & $28.3 \pm 0.4 a$ \\
\hline Group 3 & 66.0 & 27.7 & 14.4 & $45.9 \pm 0.4 a$ & 49 & 37 & 5.4 & $42.9 \pm 0.1 \mathrm{a}$ & 1.62 & 0.86 & 11.2 & $1.14 \pm 0.01 \mathrm{a}$ & 46.4 & 13.4 & 18.3 & $28.6 \pm 0.3 a$ \\
\hline Group 4 & 50.5 & 17.6 & 20.8 & $33.4 \pm 0.6 c$ & 47 & 33 & 7.1 & $41.4 \pm 0.3 b$ & 1.59 & 0.63 & 16.2 & $0.97 \pm 0.01 b$ & 36.2 & 2.0 & 36.5 & $18.2 \pm 0.6 b$ \\
\hline Group 5 & 55.9 & 24.6 & 15.6 & $37.8 \pm 0.5 b$ & 51 & 38 & 6.0 & $43.3 \pm 0.2 \mathrm{a}$ & 1.54 & 0.73 & 13.7 & $0.97 \pm 0.01 b$ & 35.4 & 4.6 & 28.1 & $19.9 \pm 0.5 b$ \\
\hline
\end{tabular}

Means of groups followed by the same letters do not differ statistically of Tukey post-hoc comparisons $(P<0.05)$. 


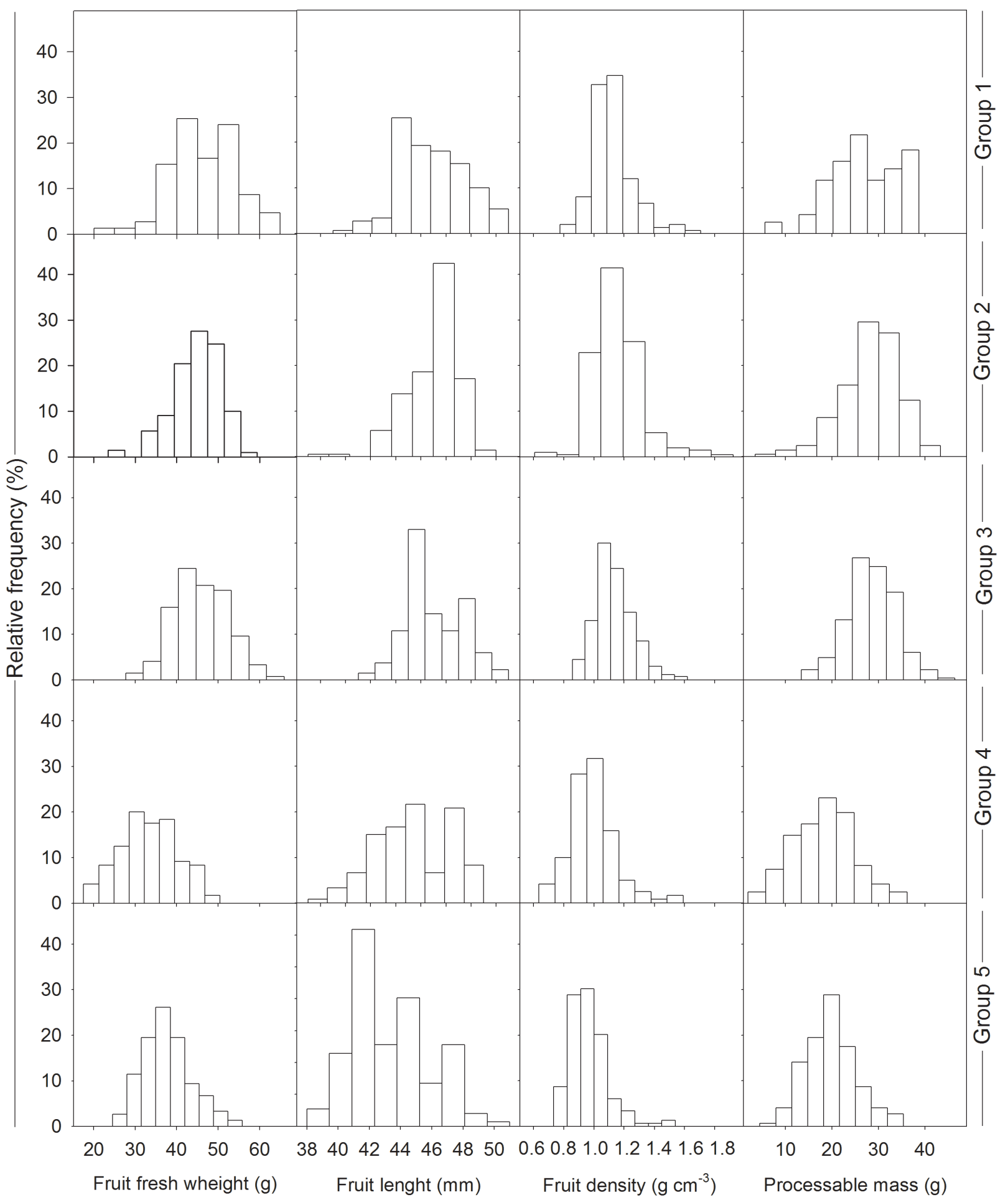

Figure 3. Percentage frequency distribution for the weight ( $\mathrm{g}$ ), equatorial diameter ( $\mathrm{mm}$ ), and density ( $\mathrm{g} \mathrm{cm}-3)$ of Acrocomia aculeata fruit exposed to different intensities of fire in the field based on the tree groupings.

had statistically lower fruit length than the other groups (Tab. 2). The fruit density of plants from groups 1,2 , and 3 was concentrated between 1.0 to $1.2 \mathrm{~g} \mathrm{~cm}^{-3}$. The mean fruit density of plants from groups 4 and 5 was statistically lower than the other groups, and was more concentrated between 0.8 and $1.0 \mathrm{~g} \mathrm{~cm}^{-3}$ (Fig. 3).

Compared to group 1 (control), the fire caused significant losses in fruit processable mass when the fruit were burned 
(groups 4 and 5); however, there was no difference when the fire only reached the stipe (groups 2 and 3) (Tab. 2). Frequency distributions showed that processable mass was primarily concentrated between 10 to $25 \mathrm{~g}$ in groups 4 and 5 versus 20 to $35 \mathrm{~g}$ in groups 1, 2, and 3 (Fig. 3 ).

Fire had no direct effect on seed biometry variables. The plants from group 2 had the highest value for fresh seed weight (Tab. 3). Significantly lower fresh seed weight was recorded in fruit from groups 4 and 5 compared to group 2. Fresh seed weight ranged from $0.09 \mathrm{~g}$ (group 3) to $3.42 \mathrm{~g}$ (group 2) (Fig. 4). Group 1 (control) had significantly lower seed length compared with all of the groups exposed to fire (Tab. 3). Group 5 had the highest amplitude for seed length, with values ranging from $5.0 \mathrm{~mm}$ to $29 \mathrm{~mm}$, with groups 2 and 4 containing the maximum value (Tab. 3 , Fig. 4 ). The fire did not cause any significant changes to seed density (Tab. 3), with values ranging from $0.18 \mathrm{~g} \mathrm{~cm}^{-3}$ (group 3) to $2.6 \mathrm{~g} \mathrm{~cm}^{-3}$ (group 5). The macaw palm fruit had a heavy and thick endocarp, weighing from $3.3 \mathrm{~g}$ to $14.73 \mathrm{~g}$ (Fig. 4) and $2 \mathrm{~mm}$ to $7 \mathrm{~mm}$ in thickness, respectively (data on endocarp

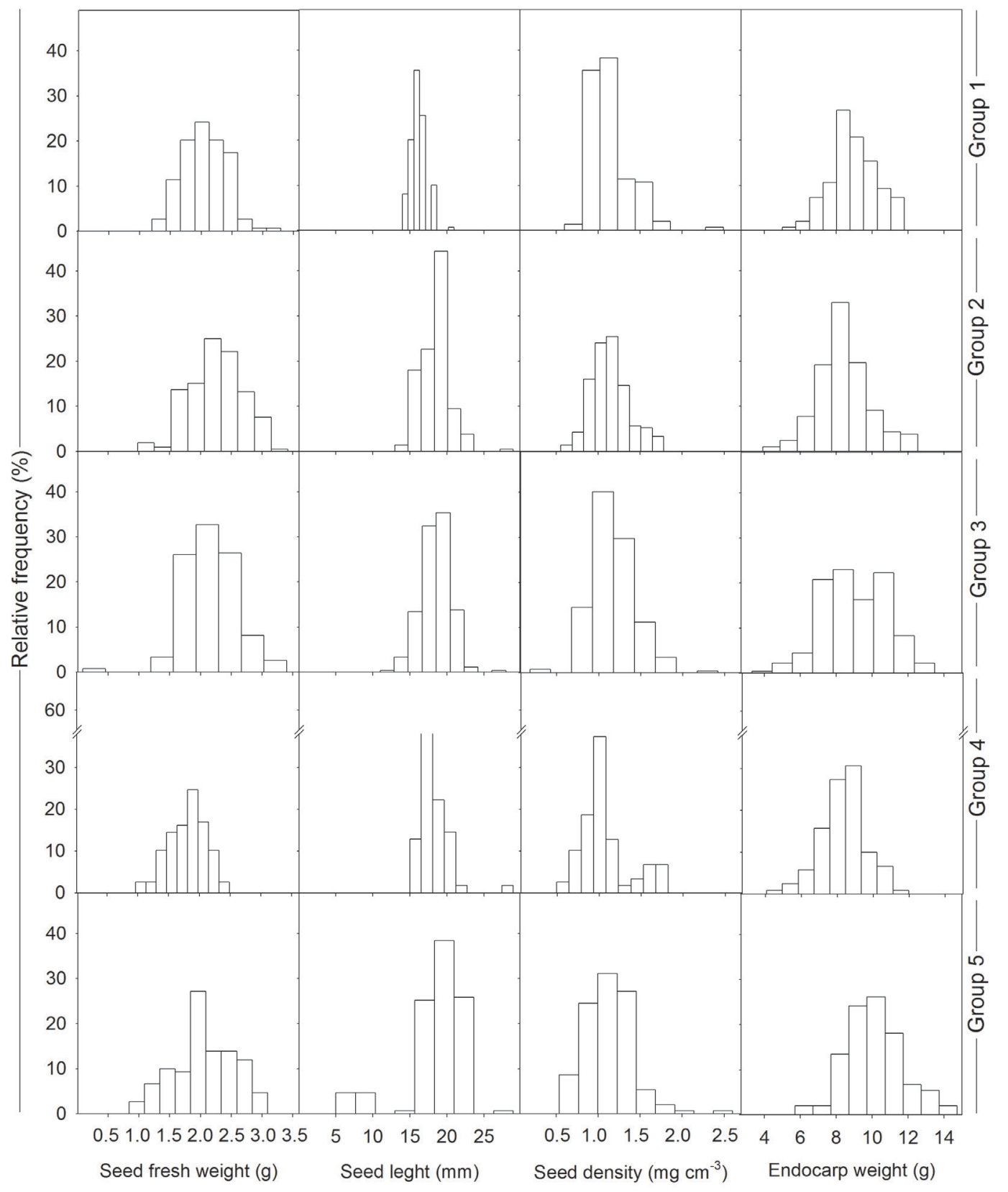

Figure 4. Percentage frequency distribution for the weight ( $\mathrm{g}$ ), length (mm), and density $\left(\mathrm{g} \mathrm{cm}^{-3}\right)$ of the seeds, in addition to the weight of the endocarp, of Acrocomia aculeata exposed to different intensities of fire in the field based on the tree groupings. 


\section{Elisa Monteze Bicalho, Bruno Luan Rosa, Anna Elisa de Souza, Camilla Oliveira Rios and Eduardo Gusmão Pereira}

thickness not shown). Endocarp weight was significantly higher in fruit from group 5. Fruit from groups 1 and 3 had the lowest values, while fruit from groups 2 and 4 had intermediate values (Tab. 3).

No differences were found among groups with respect to the extent of lipid peroxidation, which was measured from the amount of malondialdehyde (MDA) (Tab. 4). The tetrazolium test also showed that the fire did not interfere with the percentage of vigorous embryos, with no significant differences being found among the control (group 1) and the groups with burned trees (groups 2 to 5). In contrast, embryos from the fruit of group 3 (where fire reached close to the bunches) had higher viability than those from fruit in group 5 (Tab. 4).

Table 3. Maximum (max), minimum (min), variation coefficient (CV\%), mean and standard error of weight (g), length (mm), density $\left(\mathrm{g} \mathrm{cm}^{-3}\right.$ ) of seeds, and endocarp weight (g) of Acrocomia aculeata fruits exposed to different intensities of fire in the field. Group 1: plants not affected by fire; Group 2: plants affected by fire at the stipe base; Group 3: plants affected by fire near to the bunches; Groups 4 and 5: plants affected by fire at bunch height, with burned fruits.

\begin{tabular}{|c|c|c|c|c|c|c|c|c|c|c|c|c|c|c|c|c|}
\hline & \multicolumn{4}{|c|}{ Seed fresh weight (g) } & \multicolumn{4}{|c|}{ Seed lenght (mm) } & \multicolumn{4}{|c|}{ Seed density $\left(\mathrm{g} \mathrm{cm}^{-3}\right)$} & \multicolumn{4}{|c|}{ Endocarp weight (g) } \\
\hline & $\max$ & $\min$ & $\mathrm{CV}_{\%}$ & mean & $\max$ & $\min$ & $\mathrm{CV}_{\%}$ & mean & $\max$ & $\min$ & $\mathrm{CV}_{\%}$ & mean & $\max$ & $\min$ & $\mathrm{CV}_{\%}$ & mean \\
\hline Group 1 & 3.3 & 1.2 & 17.2 & $2.0 \pm 0.0 \mathrm{bc}$ & 21 & 14 & 7.2 & $16.1 \pm 0.1 b$ & 2.5 & 0.6 & 21.6 & $1.1 \pm 0.0 \mathrm{a}$ & 11.8 & 5.0 & 14.6 & $8.9 \pm 0.1 b$ \\
\hline Group 2 & 3.4 & 1.0 & 18.9 & $2.3 \pm 0.0 \mathrm{a}$ & 29 & 13 & 11.1 & $18.6 \pm 0.1 \mathrm{a}$ & 1.8 & 0.6 & 19.9 & $1.1 \pm 0.0 \mathrm{a}$ & 12.5 & 3.9 & 17.2 & $8.4 \pm 0.1 c$ \\
\hline Group 3 & 3.4 & 0.1 & 20.1 & $2.2 \pm 0.0 \mathrm{ab}$ & 28 & 11 & 11.6 & $18.5 \pm 0.1 \mathrm{a}$ & 2.4 & 0.2 & 21.6 & $1.2 \pm 0.0 \mathrm{a}$ & 13.5 & 3.3 & 19.8 & $9.0 \pm 0.1 b$ \\
\hline Group 4 & 2.5 & 1.0 & 17.3 & $1.8 \pm 0.0 c$ & 29 & 15 & 11.1 & $18.3 \pm 0.2 \mathrm{a}$ & 1.8 & 0.5 & 27.7 & $1.1 \pm 0.0 \mathrm{a}$ & 12.0 & 4.1 & 15.8 & $8.3 \pm 0.1 c$ \\
\hline Group 5 & 3.1 & 0.8 & 24.0 & $2.1 \pm 0.0 \mathrm{~b}$ & 29 & 05 & 21.8 & $18.5 \pm 0.3 a$ & 2.6 & 0.5 & 25.6 & $1.1 \pm 0.0 \mathrm{a}$ & 14.7 & 5.7 & 15.8 & $10.1 \pm 0.1 \mathrm{a}$ \\
\hline
\end{tabular}

Means of groups followed by the same letters do not differ statistically of Tukey post-hoc comparisons $(P<0.05)$.

Table 4. Mean values found for the extent of lipid peroxidation, based on the amount of MDA (malondialdehyde) and tetrazolim, in relation to the percentage of viable and vigorous embryos of Acrocomia aculeata seeds. Group 1: plants not affected by fire; Group 2: plants affected by fire at the stipe base; Group 3: plants affected by fire near to the bunches; Groups 4 and 5: plants affected by fire at bunch height, with burned fruits.

\begin{tabular}{|c|c|c|c|}
\hline & MDA (nmol g $\mathrm{Fw}^{-1}$ ] & Viables [\%] & Vigorous [\%] \\
\hline Group 1 & $1.43 \pm 0.26 \mathrm{a}$ & $72.5 \pm 11.1 \mathrm{ab}$ & $72.5 \pm 11.1 \mathrm{a}$ \\
\hline Group 2 & $1.53 \pm 0.41 \mathrm{a}$ & $80.0 \pm 7.56 \mathrm{ab}$ & $78.6 \pm 7.38 \mathrm{a}$ \\
\hline Group 3 & $1.46 \pm 0.49 \mathrm{a}$ & $87.8 \pm 5.21 \mathrm{a}$ & $77.8 \pm 7.95 \mathrm{a}$ \\
\hline Group 4 & $1.20 \pm 0.38 \mathrm{a}$ & $57.5 \pm 10.3 \mathrm{ab}$ & $52.5 \pm 15.5 \mathrm{a}$ \\
\hline Group 5 & $1.58 \pm 0.49 \mathrm{a}$ & $50.0 \pm 10.9 \mathrm{~b}$ & $50.0 \pm 10.9 \mathrm{a}$ \\
\hline
\end{tabular}

Means of groups followed by the same letters do not differ statistically of Tukey post-hoc comparisons $(P<0.05)$.

\section{Discussion}

Fire events are occurring more frequently with current climate change (Ooi et al. 2014). In the region of Minas Gerais State, where the present study was conducted, burning events are more noticeable during the dry season, when low atmospheric humidity promotes fire scattering (Lemos et al. 2012). These events tend to occur in pastures and open areas where macaw palm grow. When the fire spread for 2 days in 2011, the dry herbaceous component of the pasture around the macaw palm trees, along with dead leaves that are still attached to trees, allowed the flames to reach bunches supporting fruit in the final stage of maturity. However, some palms were only exposed to fire at the bottom of the trunks, as demonstrated by the UPGMA analysis. Plants often have traits that help protect them against certain biotic or abiotic stressors/disturbances in the environment (Trabaud 1987). For instance, our results on seed density and fresh weight confirmed that structures of the macaw palm fruit protected the seeds exposed to the fire against the effects of high temperature. Furthermore, the lignified fruit structures in macaw palm do not limit seed imbibition or promote physical dormancy (Ribeiro et al. 2011; Bicalho et al. 2015). Besides certain fruit traits might be advantageous in fire-prone environments, there was no evidence that fire is a selective agent for fruit traits in the macaw palm, as detected for other plant species (Bradshaw et al. 2011). The strategy of enclosing the seeds in a lignified covering, such as the endocarp of the macaw palm, is related to the protection of seeds against seed-eaters and, occasionally, against the eventual exposure of seeds to intense fire (Orians \& Milewski 2007). The thick macaw palm endocarp also has a protective role against predation in the natural environment (Pereira et al. 2014).

The effects of fire on fruit biometric variables were related to the burning of the pericarp and mesocarp, indicating the 
protective role of the endocarp on seed variables. Besides endocarp thickness, the protection of seeds against high temperatures might be achieved by the insulating capacity of other fruit tissues, such as the moist mucilaginous mesocarp of macaw palm fruit (Coimbra \& Jorge 2011; Reis et al. 2012). Thick fruit tissues combined with high water content prevent the internal seed temperature from rising in the large sized fruit of Kielmeyera coriacea, which is a widely distributed tree species in the Cerrado (Cirne \& Miranda 2008).

Pronounced fruit abscission immediately after the spread of fire might be related to the pedicel of the fruit being damaged by flames, or due to the secondary effects of high temperature, such as water loss, high respiration rate, and limited translocation, as reported by other authors (Addicott \& Lynch 1955; Cremer 1965; Cirne \& Miranda 2008). It is important to highlight that the fire passed through the trees when all fruits were still attached to the trees (before collection in 2011 October), since the period of burning may affect seed response to fire. For instance, sensitivity to fire is higher in early fruit development and lower after late fruit developmental stages or when dispersion has already occurred (Kaplan \& Gutman 1999; Schmidt et al. 2005). Studies are been carried out in order to investigate the post-dispersion sensitivity of macaw palm seeds to fire, because this species forms long-term soil seed banks (Ribeiro et al. 2012).

The loss of processable mass might limit the use of macaw palm fruit for biofuel production in areas prone to fire events. Aside from the high lipid content of fruit processable mass, the mesocarp contains a high concentration of carotenoids, tocopherols, and fibers (Hiane et al. 2005; Coimbra \& Jorge 2011), which might deteriorate when exposed to high temperatures (Barrera-Arellano et al. 1999). However, adult plants of macaw palm might suppress the effects of fire on their trunks, because low mortality was observed after burning. While arborescent monocots do not have bark (Tomlinson 2006) that confers protection from fire (Pausas 2015), there is no superficial meristematic cambium, which would otherwise be vulnerable to fire, pathogens, and trauma (Tomlinson 2006). In fact, because there is no damage to the apical meristem, palm species, including $A$. aculeata, might resist, or even benefit, from fire of low intensity, due to the compensatory effects of increased flowering and leaf production by individuals (Mandle et al. 2015), or at the community resilience level (Souza \& Martins 2004; Mandle et al. 2015).

Fire resistance might be associated with the functional traits of all organs throughout the plant life cycle because fire events could occur at any stage of plant development (Trabaud 1987). Seeds that are resistant to fire tend to have a thick seed coat, such as the heavy macaw palm endocarp (Tab. 3), that prevent the seeds from being exposed to high temperatures during fire (Cirne \& Miranda 2008). Consequently, this phenomenon protects the inner structures of plants. The presence of a stiff endocarp in the macaw palm might limit seed germination (Baskin \& Baskin 2014; Carvalho et al. 2015). However, the macaw palm endocarp does not act as a barrier for water movement into the seed (Ribeiro et al. 2011; Mazzottini-dos-Santos et al. 2015). The promotion of germination by fire in seeds with seed-coat dormancy is related to the scarification of the tegument and the rupturing of the seed coat or the melting of the seed-coat wax; thus, promoting water uptake (Kozlowski \& Pallardy 2002; Danthu et al. 2013). Even for seeds with hard coats that are dependent on fire to break dormancy, the heat and the duration of exposure either promote germination or are lethal to embryos (Trabaud 1987; Danthu et al. 2003; Cirne \& Miranda 2008). However, the embryos from the fruit of the macaw palm that were exposed to fire were able to maintain around $50 \%$ viability and vigor, which was a statistically similar value to that obtained for plants not exposed to fire (control). In fact, the development and maturation of seeds and embryos of the macaw palm were probably almost complete (i.e., at the end of last phase of development, according to Mazzottinidos-Santos et al. 2015) when the fire occurred and the fruit were collected in this study. The stiff endocarp might protect the macaw palm embryo against oxidative damage caused by high temperatures, as highlighted by the low MDA values. The MDA content found in the present study was much lower than that found in a previous report on macaw palm embryos, with this phenomenon occurring through protection by tocopherols (Barreto et al. 2014). The viability and germination of some Cerrado plant species might not be impaired by transitory exposure to high temperatures during fire (Fichino et al. 2016). However, the increasing frequency of burning events might affect the composition of plant species and, consequently, community structure, resulting in plants that are more resistant to disturbance gaining dominance (Zaidan \& Carreira 2008). The resistance of macaw palm propagules might contribute to the widespread distribution of this plant in the Cerrado domain (Motta et al. 2002), allowing seed survival, even after the passage of fire.

In conclusion, the structures of the macaw palm fruit, including its lignified endocarp and insulating and mucilaginous mesocarp, protect seed biometric characteristics from fire, and maintain the viability of embryos by preventing oxidative damage. Even if these fruit structures are not evolutionarily related to fire, they might allow seeds to persist despite increasingly common fire events under expected climatic change scenarios. This phenomenon will likely contribute to the distribution of $A$. aculeata expanding throughout tropical America.

\section{Acknowledgements}

We are grateful to Mr. Onori, for allowing access to the study area for the collection of material. This work had financial support from FAPEMIG (grant number APQ01244-13 to E.G.P) and CNPq (grant number 470116/20137 to E.G.P). 


\section{Elisa Monteze Bicalho, Bruno Luan Rosa, Anna Elisa de Souza, Camilla Oliveira Rios and Eduardo Gusmão Pereira}

\section{References}

Addicott FT, Lynch RS. 1955. Physiology of abscission. Annual Review of Plant Physiology 6: 211-238.

Barrera-Arellano D, Ruiz-Méndez V, Ruiz GM, Dobarganes C. 1999. Loss of tocopherols and formation of degradation compounds in triacylglycerol model systems heated at high temperature. Journal of the Science of Food and Agriculture 79: 1923-1928.

Barreto LC, Garcia QS, Morales M, Müller M, Munné-Bosch S. 2014. Vitamin $\mathrm{E}$ and defense-related phytohormones are reliable markers of embryo growth in macaw palm fruits exposed to various storage conditions. Plant Cell, Tissue and Organ Culture 118: 203-213.

Baskin JM, Baskin CC. 2014. What kind of seed dormancy might palms have? Seed Science Research 24: 17-22.

Bicalho EM, Pintó-Marijuan M, Morales M, Müller M, Munné-Bosch S, Garcia QS. 2015. Control of macaw palm seed germination by the gibberellin/abscisic acid balance. Plant Biology 17: 990-996.

Bradshaw SD, Dixon KW, Hopper SD, Lambers H, Turner SR. 2011. Little evidence for fire-adapted plant traits in Mediterranean climate regions. Trends in Plant Science 16: 69-76.

Carvalho VS, Ribeiro LM, Lopes PSN, et al. 2015. Dormancy is modulated by seed structures in palms of the cerrado biome. Australian Journal of Botany 63: 444-454.

Cirne P, Miranda HS. 2008. Effects of prescribed fires on the survival and release of seeds of Kielmeyera coriacea (Spr.) Mart.(Clusiaceae) in savannas of Central Brazil. Brazilian Journal of Plant Physiology 20: 197-204

Clarke PJ, Lawes MJ, Midgley JJ, et al. 2013. Resprouting as a key functional trait: how buds, protection and resources drive persistence after fire. New Phytologist 197: 19-35.

Coimbra MC, Jorge N. 2011. Proximate composition of guariroba (Syagrus oleracea), jerivá (Syagrus romanzoffiana) and macaúba (Acrocomia aculeata) palm fruits. Food Research International 44: 2139-2142.

Cremer KW. 1965. Effects of fire on seedshed from Eucalyptus regnans. Australian Forestry 29: 252-262.

Danthu P, Ndongo M, Diaou M, et al. 2003. Impact of bush fire on germination of some West African acacias. Forest Ecology and Management 173: 1-10.

Du Z, Bramlage WJ. 1992. Modified thiobarbituric acid assay for measuring lipid oxidation in sugar-rich plant tissue extracts. Journal of Agricultural and Food Chemistry 40: 1566-1570.

Fichino BS, Dombroski JRG, Pivello VR, Fidelis A. 2016. Does Fire Trigger Seed Germination in the Neotropical Savannas? Experimental Tests with Six Cerrado Species. Biotropica 48: 181-187.

Gignoux J, Clobert J, Menaut J-C. 1997. Alternative fire resistance strategies in savanna trees. Oecologia 110: 576-583.

Hiane P, Ramos Filho M, Ramos M, Macedo M. 2005. Bocaiúva, Acrocomia aculeata (Jacq.) Lodd., pulp and kernel oils: characterization and fatty acid composition. Brazilian Journal of Food Technology 8: 256-259.

Hoffmann WA, Solbrig OT. 2003. The role of topkill in the differential response of savanna woody species to fire. Forest Ecology and Management 180: 273-286.

Kaplan D, Gutman M. 1999. Phenology of Quercus ithaburensis with emphasis on the effect of fire. Forest Ecology and Management 115: 61-70.

Kozlowski TT, Pallardy SG. 2002. Acclimation and adaptive responses of woody plants to environmental stresses. The Botanical Review 68: 270-334.

Lemos CF, Justino FB, Costa LC, Maddock JEL. 2012. Spatial distribution of the Haines index for Minas Gerais by analysis of average atmosphere. Revista Brasileira de Agropecuária Sustentável 2: 132-143.

Long RL, Gorecki MJ, Renton M, et al. 2015. The ecophysiology of seed persistence: a mechanistic view of the journey to germination or demise. Biological Reviews 90: 31-59.

Mandle L, Ticktin T, Zuidema PA. 2015. Resilience of palm populations to disturbance is determined by interactive effects of fire, herbivory and harvest. Journal of Ecology 103: 1032-1043.
Mazzottini-dos-Santos HC, Ribeiro LM, Mercadante-Simões MO, Sant'Anna-Santos BF. 2015. Ontogenesis of the pseudomonomerous fruits of Acrocomia aculeata (Arecaceae): a new approach to the development of pyrenarium fruits. Trees 29: 199-214.

Moreira B, Tormo J, Estrelles E, Pausas JG. 2010. Disentangling the role of heat and smoke as germination cues in Mediterranean Basin flora. Annals of Botany 105: 627-635.

Motta Pd, Curi N, Oliveira-Filho AD, Gomes JBV. 2002. Ocorrência da macaúba em Minas Gerais: relação com atributos climáticos, pedológicos e vegetacionais. Pesquisa Agropecuária Brasileira 37: 1023-1031.

Ooi MKJ, Denham AJ, Santana VM, Auld TD. 2014. Temperature thresholds of physically dormant seeds and plant functional response to fire: variation among species and relative impact of climate change. Ecology and Evolution 4: 656-671.

Orians GH, Milewski AV. 2007. Ecology of Australia: the effects of nutrientpoor soils and intense fires. Biological Reviews 82: 393-423.

Pausas JG. 2015. Bark thickness and fire regime. Functional Ecology 29: 315-327.

Pausas JG, Bradstock RA, Keith DA, Keeley JE. 2004. Plant functional traits in relation to fire in crown-fire ecosystems. Ecology 85: 1085-1100.

Pereira AC, Fonseca FS, Mota GR, et al. 2014. Ecological interactions shape the dynamics of seed predation in Acrocomia aculeata (Arecaceae). PloS one 9: e98026.

Pires TP, Souza ES, Kuki KN, Motoike SY. 2013. Ecophysiological traits of the macaw palm: a contribution towards the domestication of a novel oil crop. Industrial Crops and Products 44: 200-210.

Reis SB, Mercadante-Simões MO, Ribeiro LM. 2012. Pericarp development in the macaw palm Acrocomia aculeata (Arecaceae). Rodriguésia 63: 541-549.

Reyes O, Trabaud L. 2009. Germination behaviour of 14 Mediterranean species in relation to fire factors: smoke and heat. Plant Ecology 202: 113-121.

Ribeiro LM, Garcia QS, Oliveira DMT, Neves SC. 2010. Criteria for tetrazolium tests in the estimation of the germination potential of macaw palm. Pesquisa Agropecuária Brasileira 45: 361-368.

Ribeiro LM, Oliveira TGS, Carvalho VS, Silva PO, Neves SC, Garcia QS. 2012. The behaviour of macaw palm (Acrocomia aculeata) seeds during storage. Seed Science and Technology 40: 344-353.

Ribeiro LM, Souza PP, Rodrigues Jr AG, Oliveira TGS, Garcia QS. 2011. Overcoming dormancy in macaw palm diaspores, a tropical species with potential for use as bio-fuel. Seed Science and Technology 39: 303-317.

Russell-Smith J, Gardener MR, Brock C, Brennan K, Yates CP, Grace B. 2012. Fire persistence traits can be used to predict vegetation response to changing fire regimes at expansive landscape scales - an Australian example. Journal of Biogeography 39: 1657-1668.

Schmidt IB, Sampaio AB, Borghetti F. 2005. Effects of the season on sexual reproduction and population structure of Heteropterys pteropetala (Adr. Juss.), Malpiguiaceae, in areas of Cerrado sensu stricto submitted to biennial fires. Acta Botanica Brasilica 19: 927-934.

Slik JWF, Breman FC, Bernard C, et al. 2010. Fire as a selective force in a Bornean tropical everwet forest. Oecologia 164: 841-849.

Souza AF, Martins FR. 2004. Population structure and dynamics of a neotropical palm in fire-impacted fragments of the Brazilian Atlantic Forest. Biodiversity \& Conservation 13: 1611-1632.

Tomlinson PB. 2006. The uniqueness of palms. Botanical Journal of the Linnean Society 151: 5-14.

Trabaud L. 1987. Natural and prescribed fire: survival strategies of plants and equilibrium in mediterranean ecosystems. In: Tenhunen JD, Catarino FM, Lange OL, Oechel WC. (eds.) Plant response to stress: functional analysis in mediterranean ecosystems. Berlin, Springer Berlin Heidelberg. p. 607-621.

Williams PR, Congdon RA, Grice AC, Clarke PJ. 2003. Fire-related cues break seed dormancy of six legumes of tropical eucalypt savannas in north-eastern Australia. Austral Ecology 28: 507-514.

Zaidan LB, Carreira RC. 2008. Seed germination in Cerrado species. Brazilian Journal of Plant Physiology 20: 167-181. 